\title{
Böök syndrome
}

INSERM

\section{Source}

INSERM. (1999). Orphanet: an online rare disease and orphan drug data base. Böök syndrome. ORPHA:1262

Book syndrome is a rare autosomal dominant ectodermal dysplasia syndrome reported in a Swedish family ( 25 cases from 4 generations), and one isolated case, and is characterized by premolar aplasia, hyperhidrosis, and premature graying of the hair. Additional features reported in the isolated case include a narrow palate, hypoplastic nails, eyebrow anomalies, a unilateral simian crease, and poorly formed dermatoglyphics. 